\title{
ODNOS REDOVNOG SUDSKOG I USTAVNOSUDSKOG POSTUPKA U USTAVNIM TUŽBAMA
}

Dr. sc. Aldo Radolović, redoviti profesor

Pravni fakultet Sveučilišta u Rijeci

Sudac u mirovini

Ustavni sud Republike Hrvatske
UDK: 347.91/.95

Ur.: 9. siječnja 2017.

Pr.: 10. veljače 2017.

Pregledni znanstveni rad

\section{Sažetak}

Ovaj rad tematizira odnos redovnog sudskog $i$ ustavnosudskog postupka u ustavnim tužbama. Ustavna zaštita protiv pojedinačnih akata nadležnih tijela državne vlasti (pretežito protiv odluka redovnih sudova) je supsidijarna, tj. građani i pravne osobe se Ustavnom sudu RH mogu obratiti tek nakon što su prethodno iscrpili sve mehanizme redovnog rješavanja. Ustavni postupak novi je postupak, ali ne može i ne smije biti toliko nov da ne slijedi pravila redovnog sudskog postupka. U tom je smislu ustavni postupak pred Ustavnim sudom $i$ "nov" $i$ "star". Nov utoliko što Ustavni sud ima pravo na svoje određene $i$ specifične norme postupanja, a star u tomu što slijedi pravila redovnog postupanja iz kojeg je ustavni spor proizašao i bez čijeg poznavanja ni pravilna ustavnosudska konkluzija nije moguća.

Ključne riječi: Ustavni sud, ustavni postupak, ustavna tužba, redovni sudovi, redovni sudski postupak, ustavno postupovno pravo, suci, Ustav RH, Ustavni zakon o Ustavnom sudu RH, Poslovnik Ustavnog suda RH.

\section{1. $U V O D$}

Ovaj je rad rezultat prakse i iskustva autora rada kao suca Ustavnog suda Republike Hrvatske. ${ }^{1}$ Napisani tekst nije izraz osobno-kritičkih, napose ne nekakvih "osvetničkih" razloga kojih uostalom niti ne smije biti u djelu koje pledira na atribut znanstvenosti.

Ustavni sud RH (u daljnjem tekstu: Ustavni sud) u proteklom je razdoblju, bez obzira na uglavnom lošu opću i stručno-znanstvenu percepciju, sasvim sigurno dao značajan (pozitivan) doprinos razvoju relevantne ustavnopravne misli i prakse i to je činjenica koju može provjeriti i utvrditi svaka ozbiljna znanstvena analiza.

Ovaj će rad stoga, s jedne strane, ukazati na sve poboljšice u strukturi postupanja Ustavnog suda, ali će i s druge ukazati na potrebne izmjene te prakse kako bi u većoj mjeri bila ostvarena Ustavom Republike Hrvatske² (dalje u tekstu: Ustav) zamišljena

1 Mandatno razdoblje 2007.-2016. godine.

2 Narodne novine, br. 56/90, 135/97, 8/98, 113/00, 124/00, 28/01, 41/01, 55/01, 76/10, 85/10 
koncepcija tog suda.

U nekom najširem smislu riječi ovaj rad "gravitira" ustavnom postupovnom pravu (po analogiji s građanskim, kaznenim i upravnim postupovnim pravom).

Iznenađujuća je konstatacija da "ustavno postupovno (procesno) pravo" kao siguran pravni pojam ni u praksi ni u znanosti (još) nije standardiziran, nije imenovan i gotovo kao da ne postoji. ${ }^{3}$

Intrigantna je i primjedba ${ }^{4}$ da se konstrukciji instituta "ustavnog postupovnog prava" najviše opiru suci ustavnih sudova. Navodno u ime pravnog razvoja "ustavnosudskog aktivizma" koji je, međutim (kako nam se čini), u ozbiljnoj opreci s važnim ustavnim načelom predvidljivosti primjene prava.

Bez jasnih, sigurnih i unaprijed najavljenim pravilima postupanja, ustavni sudovi "klize" neminovno, prije ili kasnije, više ili manje u pravno neprihvatljive i opasne zone improvizacije i voluntarizma.

U udžbenicima ustavnog prava (ni u našim, pa čak niti u stranim) nećemo naći puno o ustavnom postupovnom pravu ili ćemo (u najboljem slučaju) naći tek neke natuknice o tomu. ${ }^{5}$ Slično vrijedi i za nastavne programe na našim pravnim fakultetima. ${ }^{6}$

Svako postupovno pravo (ustavno, građansko, kazneno, upravno) doprinos je pravnoj sigurnosti. To nisu "kočnice" razvoju društva nego uvjeti slobode, brane protiv opasnih proizvoljnosti koje uvijek prijete. To je pravo i značajno jamstvo dostojanstva suda koji vodeći konkretan postupak razrješava određeni sporni pravni odnos. ${ }^{7}$

Stranke u sporu imaju pravo unaprijed znati po kojim će i kakvim pravilima postupati sud koji će odlučivati o njihovoj stvari i moraju moći znati kakve će biti posljedice njihovih ovakvih ili onakvih postupovnih napora (npr. u parničnom

(pročišćeni tekst), 05/14.

3 Još donedavno je npr. sudac i predsjednik Ustavnog suda Republike Italije Gustavo Zagrebelsky pisao (s upitnikom): Diritto processuole costituzionale?, Milano, 1990.

4 G. Zagrebelsky, op. cit., str. 26.

5 U međuvremenu situacija se ipak ponešto promijenila. Na nekim pravnim fakultetima (npr. Rim, Napulj) postoji na razini diplomskog studija kolegij ustavnog postupovnog prava (“diritto processuale costituzionale"), a ima i vrlo ozbiljnih znanstvenih radova o tome - npr. A. Ruggeri, Alla ricerca dell' identita' del diritto processuale costituzionale, Bologna, 2009. U Njemačkoj koja nas na ovom planu više zanima (jer smo preuzeli njihov model ustavnih tužbi) situacija je još bolja, da navedemo samo dva recentnija rada: Bendo/Klein/Bendo: Verfassungsprozessrecht, C.F. Mueller, 2011. i Hillgruber/Gross: Verfassungsprozesssrecht, C.F. Mueller, 2015. Nešto prije toga zapazili smo dva posebna rada: C. Pestalozza, Die echte Verfassungsbeschwerde, Berlin, 2006. i M. Sachs, Verfassungsprozessrecht, Tuebingen, 2010.

6 Koliko nam je poznato ni na jednom od pravnih fakulteta u RH nije predviđen nastavni predmet "Ustavno postupovno (procesno) pravo". U temeljnom udžbeniku domaćeg ustavnog prava (Smerdel-Sokol, Ustavno pravo, Zagreb, 2006.) ustavno postupovno (procesno) pravo kao zaseban pojam se ne navodi. Određen osvrt na to daje, međutim, temeljni udžbenik građanskog postupovnog prava (Triva-Dika, Zagreb, 2004., str. 67-79). "Proceduralne elemente ustavnog nadzora" posebno je obradio D. Krapac (Postupak pred Ustavnim sudom RH - ustrojstvo i proceduralni elementi nadzora, Zagreb, 2014.).

7 Aspekt dostojanstva suda kao rezultat poštovanja propisane forme posebno se navodi u ključnom djelu građanskog postupovnog prava (Triva-Dika, op.cit., str. 33.). Nema dvojbe da i ustavni sudovi moraju graditi svoje dostojanstvo i inzistirati na njemu. 
postupku i tužitelj i tuženik moraju znati za posljedice njihova nedolaska na uredno zakazano ročište, a u ustavnosudskom postupku mora biti jasno što će se dogoditi ako ustavna tužba bude posve laički i nerazumljivo napisana).

Ustavna tužba kojom se pokreće postupak pred Ustavnim sudom protiv nekog pojedinačnog akta nadležne državne vlasti (u pravilu redovnih sudova) vremenski uvijek slijedi, "naslanja se" na prethodno donesene akte redovne sudske vlasti.

S time u svezi, nužna je analiza koliko (i je li uopće) redovni sudski i ustavnosudski postupak čine jednu koherentnu cjelinu ili je (moguće) ustavnosudski postupak nešto sasvim drugo, potpuno novo i nema dodirnih veza s redovnim sudskim postupkom.

Čini nam se da je u praksi ova druga linija prevladavajuća, ali ona, po našoj ocjeni, nije pravilna i valja uložiti ozbiljne napore da se ona napusti.

Stav da je ustavnosudski postupak u ustavnim tužbama nešto "novo" u odnosu na redovan sudski postupak dobar je uvod upravo u ono što Ustavni sud mora izbjeći - da se, naime, na ustavnosudskoj razini pravni problem rješava nepravnim (u pravilu političkim ili, što bi bilo još manje prihvatljivo, klijentelističko-interesnim) sredstvima.

Ustavni zakon o Ustavnom sudu Republike Hrvatske ${ }^{8}$ (dalje u tekstu: UZUS) sadrži važno pravilo (čl. 34.) da se, ako Ustavnim zakonom nije propisano drukčije, Ustavni sud u postupku podredno smisleno primjenjuje odredbe odgovarajućih postupovnih zakona (dakle, Zakona o parničnom postupku, Zakona o kaznenom postupku, Zakona o upravnom postupku).

Hrvatski ustavotvorac ovime je uputio na nužan koneksitet redovnog sudskog i ustavnosudskog postupka u ustavnim tužbama pa je upravo (i prije svega) zbog toga nejasna uglavnom prevladavajuća praksa koja ide u suprotnom smjeru.

Ni u Hrvatskoj, a niti drugdje u Europi suci ustavnih sudova ne dolaze samo iz redova sudaca, a veza (svih) ustavnih sudaca sa svijetom redovnog sudskog prava kontrolabilna je kod nas samo do pravno elementarne razine: ${ }^{9}$ da je kandidat za suca Ustavnog suda diplomirani pravnik i da ima radni staž od petnaest godina (za doktorat znanosti dvanaest godina) (čl. 5. st. 1. i 2. UZUS).$^{10}$

To (i načelno i konkretno) može ozbiljno otežavati primjenu koncepcije povezanosti redovnog sudskog i ustavnosudskog postupka u ustavnim tužbama. Mogućnost da u rješavanju ustavne tužbe sudjeluju ustavni suci koji ne poznaju redovan sudski postupak u kakvom je donesen ustavnom tužbom napadnuti pravorijek

8 Narodne novine, br. 99/99, 29/02, 49/02 (pročišćeni tekst).

9 Poznato je da je upravo Ustavni sud vodio jedan postupak zbog prigovora na pravilnost izbora sudaca Ustavnog suda (predmet M. Juričić iz 2009., Odluka Ustavnog suda Republike Hrvatske, broj: U-III-443/2009 od 30. travnja 2009. i dva izdvojena mišljenja, objavljena u Narodnim novinama, br. 65/09). Ustavni sud nije išao u kontrolu ocjene koliko je izabrani (osporeni) kandidat "istaknuti pravnik", tu su kvalifikaciju dali organi biranja (Hrvatski sabor u konačnici), a zadiranje u kvalitetu kandidata bilo bi moguće samo kada bi postojali evidentni razlozi da kandidat nije "istaknuti pravnik".

10 Neke aspekte bi možda ipak bilo moguće kontrolirati u ustavnosudskom sporu povodom izbora sudaca Ustavnog suda. Bilo bi npr. jedino logično da sudac Vrhovnog suda ima predmet pred sucem općinskog suda, a kada je riječ o "profesorima fakulteta" valja znati da asistenti i docenti nisu profesori (arg. iz st. 1. čl. 126. Ustava). 
objektivno (zakonomjerno) vodi negiranju ili barem slabljenju povezanosti redovnog sudskog i ustavnosudskog postupka.

Naš je stav da bez poznavanja (u činjeničnom i pravnom dijelu) redovnog sudskog pravorijeka nije moguća pravilna ustavnosudska konkluzija. Poznavanje predmeta redovnog suda je, dakle, condicio sine qua non, istinska praemissa minor pravilnog ustavnosudskog zaključka.

Sudac Ustavnog suda mora i kod odlučivanja o ustavnim tužbama razmišljati drukčije nego sudac redovnog suda, on iz "ptičje perspektive" promatra rad suca redovnog suda i ima pravo i obvezu "uzdignuti se" iznad obzora suca redovnog suda, ići ispred tog suca $i$ ispred zakona, ali ne bez redovnog suca i ne bez zakona.

Odlučivanje Ustavnog suda koje u tom smislu mora predstavljati kvalitativan iskorak, nužno zahtijeva i određen iskorak u formi postupanja. Tu i takvu formu, međutim, valja graditi na kontinuitetu postupanja u odnosu na redovni sud, a ne na distanciranju i napose ne na radikalnom prekidu s onim kako je postupao redovni sud.

Ustavni sud u postupcima povodom ustavnih tužbi štiti građane i pravne osobe od "povreda ljudskih prava i temeljnih sloboda" (arg. iz al. 4. čl. 129. Ustava), štiti dakle Ustav RH koji regulira ova prava i slobode. Redovni sudovi, međutim, također primjenjuju Ustav (st. 3 čl. 118. Ustava), pa to mora biti bitna dodirna točka koja i materijalnopravno i postupovnopravno povezuje redovne sudove i Ustavni sud RH.

\section{USTAVNOSUDSKE I PRAVNOPOLITIČKE PRETPOSTAVKE USTAVNOSUDSKOG RJEŠAVANJA USTAVNIH TUŽBI}

Temeljem Ustava i Ustavnog zakona o Ustavnom sudu, Ustavni sud ima dvije temeljne zadaće: kontrolu ustavnosti i zakonitosti propisa (tzv. apstraktna kontrola) i rješavanje ustavnih tužbi podnesenih protiv pojedinačnih akata mjerodavnih tijela državne vlasti (ustavne tužbe).

Premda nema dvojbe oko primarnog značaja apstraktne kontrole propisa, isto je tako izvjesno da su ustavne tužbe po svom pravnopolitičkom značaju odmah do toga.

U prilog takva zaključka govori i činjenica da u strukturi ukupno zaprimljenih predmeta u Ustavnom sudu ustavne tužbe čine čak od 80 do $90 \%$ svih predmeta. ${ }^{11}$

Tim podacima dodajmo još i ove:

- od ovoga velikog broja ustavnih tužbi najviše (opet od 80 do $90 \%$ ) je iz područja građansko-trgovačkog prava,

- $70 \%$ od ukupnog broja zaprimljenih ustavnih tužbi rješava se tzv. meritornim odbacivanjem (formulom da se "neće uzeti u razmatranje"),

- od preostalih $30 \%$ koliko se uzima u meritorno rješavanje usvaja se (ukidanjem pobijenog pojedinačnog akta) negdje oko $3 \%$.

Ovi podatci daju temelje za višestruku analizu problema ustavnih tužbi.

Poznato je, prvo, kako se sustavno plasira teza o tomu da Ustavni sud "nije redovni sud" i da intervenira "samo kada su u pitanju povrede Ustava". Takva

11 Statistički podatci koji se ovdje iznose dostupni su autoru do kojih je došao tijekom obnašanja dužnosti ustavnog suca. Općenito o statistici Ustavnog suda vidjeti detaljnije na: https://www. usud.hr/hr/statistika (posjećeno 21.1.2017.). 
percepcija, mada sadrži i mnoge točne odrednice, zapravo šteti samom Ustavnom sudu jer ga hoće smjestiti u pravni prostor izvan redovnog pravnog sustava države.

Suprotna je pozicija da je Ustavni sud nekakav najviši, gotovo super - sud i ta pozicija gura ustavno suđenje u opći prostor redovnog sudskog odlučivanja što ima za neposrednu posljedicu to da je Ustavni sud doslovno zapljusnut ogromnim brojem ustavnih tužbi koje tako prijete paraliziranjem ukupnog djelovanja Ustavnog suda.

Ustavni sud treba biti jedna kreativna sinteza jednog i drugog, u konačnici jedan sui generis državni organ koji štiti ustavni sustav zemlje.

Jedno ipak mora biti sigurno - Ustavni sud nije i ne smije biti "politički sud".

Ma koliko način biranja sudaca Ustavnog suda, način na koji se taj izbor provodi pa i kadrovski sastav Suda u proteklih 27 godina daju dosta razloga za visokopolitički značaj Ustavnog suda, Sud jednostavno ne smije biti politički sud. ${ }^{2}$

Ovdje valja podsjetiti da je u modernoj, demokratskoj pravnoj državi jedina nepravna (politička) intervencija koju u sferu pravnih odnosa dopušta ustavni poredak institut pomilovanja. ${ }^{13}$ To je u RH ovlast predsjednika Republike (al. 4. čl. 98. Ustava) koji pomilovanje daje nevezano za važeći pravni poredak.

"Ulaz" politike u pravo nije inače nepoznat problem. Čak se i ustavno pravo nekad zvalo "državno pravo". Razine "napada" politike na pravni poredak najčešće su vrlo sofisticirane, naizgled nevidljive, ali ima i takvih koje su grubo nametnute $i$ očigledne. Na ovim našim prostorima toga je pogotovo bilo dosta. ${ }^{14}$

Jedna od efikasnijih brana protiv politizacije Ustavnog suda može i mora biti i visokorazvijena, pravno sofisticirana i stručno-znanstveno kontrolabilna forma postupanja Ustavnog suda.

Takva bi forma ujedno sprječavala i to da oblik i način postupanja Suda u visokoj mjeri zavisi o osobama (i osobnosti) sudaca i predsjednika suda. ${ }^{15}$

12 Posljednji izbor sudaca Ustavnog suda baš ne ohrabruje u tom pravcu. Vrlo je, npr. nezgodno da su izabrani upravo oni kandidati čija su imena (i fotografije) u pisanim medijima objavljena čak mnogo prije formalnog početka kandidiranja i izbora. Političke stranke (koje dakako imaju legitiman utjecaj na izbor ustavnih sudaca kroz mehanizam parlamentarnog odlučivanja) moguće su ipak išle ponešto predaleko u kandidiranju i delegiranju čak i članova svog užeg političkog rukovodstva. Poznato je da je predsjednik saborskog Odbora za Ustav, poslovnik i politički sustav po obavljenom izboru novih (10) sudaca Ustavnog suda izjavio da će Ustavni sud s obzirom na ishod izbora "teško biti sud". Nadajmo se ipak da političnost neće biti dominantna smjernica novog saziva Ustavnog suda.

13 Poznate su misli velikana opće i pravne povijesti o tome (Kant, Beccaria, Radbruch). Sve je to, dajući i svoj doprinos, posebno sintetizirao Radbruch (1878.-1949.) - vidjeti novo izdanje njegova djela Rechtspfilosophie, Heidelberg, 2003. Pomilovanje je, dakle, akt državnog poglavara isključivo temeljem milosti (ex caritate) uopće ne temeljem prava. Čista politička odluka. Na bivšem federalnom prostoru dan je korektan prijevod glavnog Radbruchovog djela (G. Radbruch, Filozofija prava, Nolit, Beograd, 1980.; dio koji obrađuje pomilovanje je na str. 222.-226.).

14 Sjetimo se samo npr. sudova udruženog rada u vrijeme bivše države i bivšeg sustava. Političnost je tu i načelno (pravno propisano) dominirala nad pravom. Ti su sudovi od 1974. (1976.) do 1989. godine u potpunosti sudili sporove iz radnih odnosa ("udruženog rada").

15 Nije teško zamijetiti da npr. kazneni predmeti nisu bili posebno zanimljivi dok u Ustavni sud RH nije došao sudac koji se specijalizirano bavi kaznenim pravom. Ili da konvencijsko pravo dobiva na poletu dolaskom sudaca koji su bliži tome. Opseg odluka (od 4 stranica do 100 
Činjenica da od ukupnog velikog broja ustavnih tužbi čak od 80 do $90 \%$ otpada na građansko-trgovačko područje, ozbiljno upućuje da nešto nije u redu u sferi redovnog sudskog odlučivanja u ovom području. Tu ima puno stvari koje npr. uopće nisu prošle kroz Vrhovni sud Republike Hrvatske (dalje u tekstu: Vrhovni sud). Valja ozbiljno razmisliti o tomu da sporno pravna stvar ne može pred Ustavni sud, a da prethodno nije bila na Vrhovnom sudu kao "najvišem sudu" (st. 1. čl. 119. Ustava). Ustavni sud bez toga zapravo nema pred sobom stav redovne sudske vlasti.

Pažnju zaslužuje i daljnja činjenica da se (čak) 70 \% ustavnih tužbi "meritorno odbacuje" (čl. 71. UZUS). ${ }^{16}$

To nije i ne smije biti "diskrecijsko pravo odbačaja" ${ }^{17}$ nego mora biti rezultat prethodno izvršene i dobre pravne analize stvari. Ni u obrazloženju takve odluke Ustavni sud nije oslobođen objašnjenja zašto je tako odlučio, premda je objektivno prihvatljivo da takvo obrazloženje ipak bude ponešto jednostavnije.

Podatak da se ustavne tužbe i u Hrvatskoj i inozemstvu usvajaju vrlo rijetko (oko $3 \%$, a negdje npr. Njemačkoj i manje) ozbiljno upućuje čak i na propitivanje o samom smislu ustavnih tužbi pred Ustavnim sudom. To su razine statističke pogreške i doista je pitanje treba li zbog toga angažirati složen aparat Ustavnog suda. ${ }^{18}$

I naš je stav da nadležnost Ustavnog suda u ustavnim tužbama ima svoje opravdanje. Niska razina usvajajućih odluka dobar je znak za funkcioniranje ukupnog pravnog poretka, baš kao što bi za suprotno stanje bio opravdan poziv na nužnu pravnopolitičku intervenciju. U tom smislu, dakle, ovakva "supsidijarna" uloga Ustavnog suda ima svoje ustavno-političko opravdanje.

Mi smo u području ustavnih tužbi preuzeli njemački model da je ustavna tužba moguća protiv svih mjera javne vlasti. Mnoge države (npr. Austrija, Italija) ustavne tužbe reduciraju na odluke upravnih vlasti, dakle ne i protiv sudskih odluka.

Ne možemo zanemariti činjenicu da je naš njemački uzor mnogo veća i u svakom pogledu moćnija zemlja koja ima i posebne razloge za ustavnu ulogu Saveznog ustavnog suda o ustavnim tužbama.

Čini nam se da to ipak ne otklanja potrebu istovrsnog ustavnog rješenja u RH, mada uz našu obvezu pažnje da ovako postavljena uloga Ustavnog suda ne "zagušuje" već i onako kompliciran domaći pravni sustav.

Ustavna tužba je i jezično i pravo u različitim državama poznata pod različitim nazivima (engl. constitutional complaint, njem. Verfassungsbeschwerde, tal. ricorso costituzionale, ustavna žalba). S obzirom na to da nam njemačko pravo služi kao

stranica u sličnim stvarima) također je bio značajno određen osobnostima sudaca i predsjednika Suda. To, međutim, nije sustav.

16 Izraz "meritorno odbacivanje" kolokvijalni je izraz, jedan jezično-pravni oksimoron. Iako o tome odlučuje vijeće od tri suca, rizik sumarnog pristupa tim predmetima nije bez temelja. Pravo obrazloženje (ne bitno dugo, ali sažeto i dobro, koje napose pokazuje razumijevanje stvari) jedino otklanja prigovor sumarnosti.

17 Tako npr. ističe D. Sinović (Ustavna žalba - teorijsko pravni okvir, Anali Pravnog fakulteta u Beogradu, 1/2012., str. 205.). Meritorni odbačaj, naprotiv, mora biti pravno vezan i dokumentiran kao svaka meritorna odluka.

18 Kritičari djela i prakse Ustavnog suda, uglavnom kroz medijski prostor, posebno prigovaraju da je postotak usvajajućih ustavnih tužbi (čak i do 60 \%) mnogo veći kod tzv. VIP-predmeta (poznate osobe ili događaji). O takvim primjedbama Ustavni sud mora voditi računa. 
model - uzor bio bi ispravniji naziv "ustavna žalba". ${ }^{19}$

"Ustavna tužba" upućuje na nekakav novi pravni početak, a "ustavna žalba" produljuje postupovni kontinuitet s redovnog sudskog na ustavnosudski postupak.

Njemačko objašnjenje je suprotno, tj. naglašava kontinuitet između ova dva postupka. ${ }^{20}$ I rješenja iz njemačkog Ustavnog zakona su na toj liniji. ${ }^{21}$

Ovakva "lutanja" u pitanju (dis)kontinuiteta između redovnog sudskog i ustavnosudskog postupka imaju i svoje neposredne posljedice.

Ustavni sud kroz ustavne tužbe daje građanima i pravnim osobama zaštitu kada su povrijeđena njihova "ljudska prava i temeljne slobode" (al. 4. čl. 129. Ustava). To zvuči vrlo obećavajuće, ali nije pravno najbesprjekornije.

Ne samo da ne postoji čvrst i jasan "popis" tih ljudskih prava i temeljnih sloboda nego ne postoje niti jasni kriteriji za njihovo pobliže određivanje.

Navest ćemo u tom smislu samo nekoliko primjera. Mnoge je ustavne tužbe Ustavni sud usvojio po čl. 14. Ustava (povreda jednakosti građana). Međutim, napose u civilu, različit ishod u istim ili sličnim stvarima može biti sasvim legitiman (zakonit) ishod postupka. ${ }^{22}$

Slično je i sa zaštitom prava vlasništva. Tu čl. 48. Ustava štiti nepovredivost prava vlasništva, daje zaštitu od zadiranja javnih vlasti (redarstvenih, sanitarnih, vatrogasnih, vojnih itd.), a ne vlasništvo u njegovu građanskopravnom smislu. ${ }^{23}$

Pravo na "pravičnu odluku" (arg. iz st. 1. čl. 29. Ustava) također jako varira između materijalnopravnog i postupovnopravnog poimanja toga prava. ${ }^{24}$

U meritornom smislu po Ustavnom zakonu o ustavnom sudu Republike Hrvatske, Ustavni sud usvaja ili odbija ustavnu tužbu (st. 2. čl. 73.). Mogućnost preinačenja pobijane odluke samo je u sferi teorije. ${ }^{25} \mathrm{U}$ tom smislu valja ipak već sada

19 Na njemačkom jeziku imenica "Beschwerde" znači “žalba" (tako Uroić-Hurm, Njemačkohrvatski rječnik, Zagreb, 2004., str. 102.).

20 Tako navodi i M. Sachs, op. cit., str. 14.

21 Njemački Ustavni zakon o Ustavnom sudu (Bundesverfassungsgerichtsgesetz, od 12. ožujka 1951., pročišćeni tekst od 11. kolovoza 1993., BGB1. I S. 1473., zadnje mijenjan člankom 8. Uredbe od 31. kolovoza 2015., BGB1. I S. 1474) posebno određuje da u svakom od dva senata Saveznog Ustavnog suda mora biti po tri (ukupno, dakle, šest u Sudu) suca koji su prethodno bili (najmanje tri godine) suci nekog (ima ih šest) Saveznog vrhovnog suda (čl. 94.). M. Sachs, op. cit., str. 11. i 14. o ovakvom rješenju govori vrlo pozitivno.

22 U parničnom postupku npr. sud ispituje samo tvrdnje koje su stranke istaknule i izvodi samo dokaze koje su one predložile. Moguće je tako da u dvije posve slične stvari tužitelj A predloži svih pet mogućih dokaza (i tako dobije spor), a tužitelj B predloži samo dva dokaza i izgubi spor. Obje su odluke zakonite. Ustavni sud, osim toga, u pravilu nema pred sobom obje ove (različite) odluke pa se može dogoditi da ukine upravo onu "dobru", a ona "loša" je već pravomoćna i definitivna te se ne može promijeniti.

23 Ovako pogrešna projekcija ustavne zaštite prava vlasništva nepotrebno i bez valjane osnove vodi Ustavni sud u ispitivanje vlasničkih tužbi, stjecanje i gubitka prava vlasništva, zemljišnoknjižnog prava itd.

24 Redovni sudovi odlučuju po pravičnosti samo kada im Zakon to izrijekom dopušta (npr. Zakon o obveznim odnosima čini to na više mjesta). Izvan toga takvo suđenje nije moguće, pa tu ovlast nema ni Ustavni sud. U postupovnom smislu redovni sudovi također postupaju po načelu legaliteta, a ne po načelu pravičnosti.

25 M. Sachs, op. cit., str. 33. U našim uvjetima čini se da ovo pitanje nije aktualno. 
razmišljati o mogućnosti preinačenja ako je npr. povreda materijalnog ustavnog prava nedvojbena.

Valja razmisliti i o drugim mogućnostima ishoda ustavnosudskog postupka, npr. da Ustavni sud samo deklarira povredu ustavnog prava. Tu bi Ustavni sud slijedio Europski sud za ljudska prava. Zbog dokaza pribavljenog na nezakonit način (st. 4. čl. 29. Ustava), ali koji nije odlučan za ocjenu o krivnji i kaznenoj odgovornosti pred Ustavnim sudom pobijana kaznena presuda ne bi se mogla ukidati, a deklaracija učinjene povrede prava tijekom kaznenog postupka služila bi kao temelj odštetnom zahtjevu osuđenika. ${ }^{26}$

\section{ANALIZA KONKRETNIH OBLIKA POSTUPANJA USTAVNOG SUDA REPUBLIKE HRVATSKE U USTAVNIM TUŽBAMA}

Ovaj dio rada ima za cilj prethodno izrečene ocjene provjeriti kroz neke konkretne oblike djelovanja Ustavnog suda, bez pretenzije da takva analiza zahvati sve aspekte ustavnosudskog postupanja. Predmet zahvata dodirne su točke sličnosti i razlika između redovne sudske i ustavnosudske kompetencije.

\subsection{Sastav $i$ sadržaj ustavne tuz̆be}

Ustavnu tužbu može podnijeti svaka fizička i pravna osoba koja smatra da joj je nekim pojedinačnim aktom nadležnog tijela državne vlasti povrijeđeno neko ljudsko pravo (st. 1. čl. 62. UZUS).

Bez obzira na ovu širinu mogućnosti podnošenja ("svatko"), ovo nije nikakva actio popularis (popularna tužba), jer se podnosi protiv točno određenog akta i, gotovo se samo po sebi razumije, podnosi ju osoba koja je sudionik tog postupka i koja ulaganjem ustavne tužbe ostvaruje određen pravni interes.

UZUS traži određen sadržaj ustavne tužbe (čl. 65.) i posebno navodi da će Ustavni sud ispitati samo one povrede ustavnih prava koje su istaknute u ustavnoj tužbi (st. 1. čl. 71.). Prelazi li ustavna tužba granice nerazumljivosti, moguć je odbačaj (čl. 72.).

$\mathrm{Na}$ podnesenu ustavnu tužbu ne plaćaju se biljezi, a podnositelj u slučaju neuspjeha samo iznimno snosi troškove (čl. 80.). ${ }^{27}$

26 Deklaraciju Ustavnog suda (a slično bi vrijedilo i za deklaraciju Europskog suda za ljudska prava) ipso facto napose ne treba uzimati kao temelj za ponavljanje redovnog sudskog postupka. Ponavljanje postupka se, načelno gledano, dopušta samo zbog novokreiranog činjeničnog stanja ili zbog najtežih povreda postupka, što deklaracija počinjene, ali nebitne povrede ustavnog prava u svakom slučaju nije. U trenutku pisanja ovog rada (studeni/prosinac 2016.) medijski su aktualizirani kazneni postupci u kojima je Europski sud za ljudska prava (ESLJP) utvrdio povredu prava zbog, rekli bismo, površno odobrenog prisluškivanja osumnjičenih osoba ("šprance"). Nezgoda je u tomu što su to ključni dokazi za djela koja su vrlo teška (trgovina drogom).

27 U praksi nismo zabilježili slučaj da se podnositelju ustavne tužbe nalaže snošenje troškova. Ustavna pravda u RH je, dakle, besplatna. To je i europsko pravilo. D. Krapac upućuje (op. cit., str. 263.) na rješenje njemačkog Zakona o Saveznom ustavnom sudu gdje je Ustavni sud ovlašten izreći novčanu kaznu od 100 do 1500 eura kada je podnesena "potpuno bezizgledna" 
Uvjeti iz čl. 65. svakako su dosta niži u odnosu na postupanje pred redovnim sudovima, i to u više pravaca:

- redovni sudski postupak u pravilu je mnogo skuplji (prije svega parnični),

- u redovnom sudskom postupku (opet, prije svega parničnom) nužno je stavljanje određenog tužbenog zahtjeva,

- neki aspekti forme mnogo su jači pred redovnim sudom (npr. zastupanje za reviziju), ${ }^{28}$

- izlaganje pravne osnove ${ }^{29}$ nije obveza u redovnom sudskom, a u ustavnosudskom postupku čini se da je ipak donekle potrebno.

Valjalo bi pristupiti znanstvenoj sociološko-pravnoj analizi predmetne ustavnosudske regulacije. Čini se da doprinosi već uočenoj pojavi "špranciranja" ustavnih tužbi, što nije dobar proces i vodi bagateliziranju ustavnih tužbi.

Čl. 65. UZUS-a (za razliku od npr. čl. 106. i 186. ZPP-a) nema odredbe o tome da ustavna tužba sadrži oznaku "stranaka". Upadljivo u UZUS-u nedostaje oznaka pasivno legitimirane strane.

Pitanje o tomu tko je stvarno ta pasivna strana u ustavnosudskom postupku nadilazi pretenzije ovog rada. U svakom slučaju dvojba je samo između toga je li to protivna strana iz redovnog sudskog postupka ili je to jedan novi subjekt - država. ${ }^{30}$

Stranka podnosi ustavnu tužbu sama ili preko punomoćnika (st. 1. čl. 24. UZUS). Tu se slijedi logika redovnih sudskih postupaka. Punomoć iz parnice važi i za ovrhu, djelomično (šest mjeseci) i za ponavljanje postupka, ${ }^{31}$ ali za podnošenje ustavne tužbe

ustavna tužba. U redovnom sudskom postupku, naravno, redovito se plaćaju biljezi i snosi troškove, u civilu prije svega.

28 Po izmjeni Zakona o parničnom postupku od 1. listopada 2008. godine, Narodne novine, br. 84/08, prema st. 1. čl. 91.a stranka može podnijeti reviziju preko punomoćnika koji je odvjetnik. Sama, dakle, ne može, a ne može ni preko punomoćnika koji nije odvjetnik (iznimno je da je samo stranka pravnik, odnosno ima pravosudni ispit, ali to je vrlo iznimna situacija). S obzirom na to da je revizija (u civilnim stvarima), u određenom smislu "predstadij" ustavne tužbe, u projekciji kontinuiteta između ovih dvaju postupaka bilo bi razložno predviđati da ustavnosudski postupak zadržava ili čak pojačava formu zastupanja. Sadašnje rješenje je, međutim, obrnuto.

29 St. 3. čl. 186. Zakona o parničnom postupku (Narodne novine, br. 53/91, 91/92, 58/93, 112/99, $88 / 01,117 / 03,88 / 05,02 / 07,84 / 08,123 / 08,57 / 11,148 / 11,25 / 13,89 / 14$, dalje u tekstu: ZPP) određuje da pravna osnova nije obvezatan sastavni dio tužbe, a parnični sud nije vezan navedenom pravnom osnovom u tužbi. Čl. 65. UZUS-a, čini se, ipak inzistira na navođenju pravne osnove ustavnosudskog spora. Traži "naznaku ustavnog prava za koje se tvrdi da je povrijeđeno" i naznaku "mjerodavne odredbe Ustava koje to pravo jamče". To je zapravo pravna osnova ustavnog spora i načelno je dobro da se pitanje pravne osnove spora u ustavnosudskom postupku diže na višu razinu. S tim, međutim, nije spojiva kreirana situacija da ne postoji obveza zastupanja po profesionalnim punomoćnicima. Takva obveza npr. postoji u Austriji (st. 2. čl. 17. Zakona o Ustavnom sudu Republike Austrije, Verfassungsgerichtshofgesetz, BGBl. Nr. 85/1953, zadnja izmjena BGBl. I. Nr. 24/2017).

30 RH npr. ima posebnog zastupnika u postupcima pred ESLJP-om (čl. 2. Uredbe o Uredu zastupnika Republike Hrvatske pred Europskim sudom za ljudska prava od 9. veljače 2012. godine, Narodne novine, br. 18/12 ). S obzirom na nedvojbenu razinu sličnosti kompetencija Ustavnog suda i ESLJP-a bilo bi jedino pravilno rješenje da sličan zastupnik zastupa RH u ustavnosudskim postupcima pred Ustavnim sudom.

31 Parnična punomoć vrijedi i za reviziju (arg. iz čl. 95. ZPP), samo s time da za ulaganje revizije 
traži se posebna punomoć (st. 2. čl. 24 UZUS). Ovo rješenje UZUS-a nije na liniji kontinuiteta između redovnog sudskog i ustavnosudskog postupka, upravo razbija taj kontinuitet.

Pravni interes nije veći problem ako je stranci neko njeno pravo već povrijeđeno. ${ }^{32}$

\subsection{Odgovor na ustavnu tužbu} suda.

Ovo je možda najsuspektnije pitanje u aktualnom načinu postupanja Ustavnog

Redovni sudski postupak (civilni, kazneni, upravni) nije gotovo moguće ni zamisliti bez davanja podnesenog pravozaštitnog zahtjeva na odgovor protivnoj strani.

Ustavna i konvencijska pravila o "pravičnosti" i "jednakosti oružja” u postupanju isto bi tako eo ipso trebala nametati takvu logiku i praksu postupanja.

Domaća ustavna praksa ipak nije takva. Ona je određena nekim praktičnim razlozima (otežava postupanje i produžava trajanje postupka), ali i nekim načelima, pravno dvojbenim pa i pogrešnim gledanjem na ova pitanja.

Već smo naveli da se u domaćem ustavnosudskom postupku zna tko je "druga strana" kojoj bi ustavnu tužbu dostavili na odgovor.

UZUS ne govori o dostavi ustavne tužbe "tuženiku" na odgovor, ali sadrži pravilo (koje se odnosi na dostavu donesene odluke) da se prijepis odluke dostavlja "tijelu koje je donijelo osporeni akt te osobi koju je Ustavni sud pozvao (valjda: bio pozvao) da se izjasni” (st. 2. čl. 78.).

Ako, dakle, odluku koja je donesena treba dostaviti nadležnom državnom tijelu i osobi koja je bila pozvana "da se izjasni", onda je jedino logično da su te osobe bile i prije toga upoznate s ustavnom tužbom, tj. da im je ta ustavna tužba bila dostavljena na odgovor.

Postojeća praksa može se (i to samo donekle) pravdati tamo gdje dolazi do "meritornog odbacivanja" (a to je čak 70 \% tužbi). Tu je ustavna tužba eliminirana na samom početku postupka pa onda time ni ne treba "uznemiravati" protivnu stranu.

U svemu ostalome, nužno je davati ustavnu tužbu na odgovor "drugoj strani”, bez obzira kada ćemo, npr. zvati tužitelja ili tuženika u parnici koji je izgubio redovni spor.

Doista je teško shvatljivo da je vjerovnik kao tužitelj pravomoćno (i revizijski) dobio spor, pokrenuo ovrhu i naplatio tražbinu, a tuženik je pokrenuo ustavni spor za koji isti vjerovnik uopće ne zna niti se o njemu može izjasniti.

punomoćnik u pravilu mora biti odvjetnik.

32 D. Krapac (op. cit., str. 112.) s pravom primjećuje da je pravni interes podnositelja ustavne tužbe stvoren već samim time što se podnosi protiv pojedinačnog akta kojim je već povrijeđeno neko ustavno pravo. Taj interes može biti imovinski, ali i neimovinski. Ovaj drugi može napose biti zanimljiv u kaznenoj oblasti gdje se npr. ustavna tužba podnosi protiv odluke da se optužba odbija zbog zastare, a podnositelj traži "puno oslobođenje" ("assoluzione a formula piena"). U Sloveniji je to nedavno bio slučaj s bivšim premijerom Janšom. U RH to bi išlo dosta teško jer naš Zakon o kaznenom postupku (Narodne novine, br. 152/08, 76/09, 80/11, 121/11, 91/12, 143/12, 56/13, 145/13, 152/14, dalje u tekstu: ZKP) ne predviđa oslobađajuću presudu takvog tipa. 
U kaznenom pravu situacija je još dramatičnija. Tu državni odvjetnik ne može podnijeti ustavnu tužbu, ${ }^{33}$ a niti ustavnu tužbu koju je podnio optuženik ne dobiva na odgovor. Na sudbinu svoje optužbe pred Ustavnim sudom državni odvjetnik uopće ne može djelovati.

\subsection{Vođenje ustavnosudskog postupka}

Poznato je da se svi redovni sudski postupci vode uz poštovanje pravila postupovne kontradiktornosti, usmenosti i pismenosti (pisanosti).

Ustavnosudski postupak po ustavnim tužbama bitno odstupa od toga. Zapravo, kada već nema pravog pristupa pitanju odgovora na ustavnu tužbu, nema ga ni za kasniji slijed vođenja postupka.

Ovakvo je stanje D. Krapac ${ }^{34}$ previše eufemistički opisao kao "ograničeno načelo kontradiktornosti”.

UZUS (čl. 50.) poznaje institut "javne rasprave", tzv. savjetodavne rasprave, ${ }^{35}$ ali ne i institut "rasprave" u smislu ročišta i ročišnog usmenog raspravljanja.

Slično vrijedi i za pisanu komunikaciju sudionika postupka. Njih se ne može spriječiti da Ustavnom sudu šalju pisane podneske, ali Ustavni sud ih sam na to nije dužan pozivati (u pravilu to ni ne čini).

Problem ipak nije nerješiv ni uz ovu manjkavu ustavnosudsku regulaciju.

Kvalitetan izlaz iz problema u aktivnijoj je primjeni uloge suca-izvjestitelja čije su nadležnosti značajne (čl. 69. UZUS, čl. 30.-35. Poslovnika Ustavnog suda, ${ }^{36}$ dalje u tekstu: Poslovnik). Upravo je ova njegova istraživačko-pripremna uloga značajan stadij ukupnog ustavnosudskog postupka u kojem se mogu riješiti i pitanja odgovora na ustavnu tužbu i podići razinu usmenosti i pisanosti ustavnosudskog postupka. ${ }^{37}$

Takvo bi ponašanje suca-izvjestitelja na neki način kompenziralo inače manjkavu ustavnosudsku regulaciju o kontradiktornosti ustavnosudskog postupka i bitno održalo kontinuitet postupanja s redovnim sudom koji je donio akt kojeg ispituje Ustavni sud.

Sucima Ustavnog suda pomažu ustavnosudski savjetnici (čl. 74.-86. Poslovnika).

33 Državni odvjetnik nema aktivnu legitimaciju (ne priznaje mu se) za podnošenje ustavne tužbe u kaznenim stvarima. Izraz je to kod nas općeprihvaćenog stava da on predstavlja državu, a država ne može sama sebi povrijediti ustavna (ljudska) prava. Ovo pitanje ne bi smjelo biti dovršeno. Aktivna ustavna legitimacija javnopravnih osoba je kako kaže prof. C. Pestalozza (op. cit., str. 8.) "ein unsicheres Terrain" (nesiguran teren) i tu valja otvoriti mogućnost dodatnih znanstvenih istraživanja. Osim toga, zašto ne bi Državnom odvjetniku aktivna legitimacija bila priznata zbog načela vladavine prava kao vrhunske vrednote ustavnopravnog poretka (čl. 3 . Ustava)? Stanje stvari je za državnog odvjetnika i još gore od toga - on ni ne zna da je optuženik ustavnom tužbom napao pravomoćni kazneni pravorijek niti se o tome obavještava.

34 D. Krapac, op. cit., str. 79.

35 Ustavni sud dosta rijetko prakticira "savjetodavne rasprave" (svega tri u ukupnom proteklom razdoblju).

36 Narodne novine, br. 83/14 (pročišćeni tekst).

37 Kvaliteta pripremljenog materijala kojeg prikuplja sudac-izvjestitelj odlučujuće određuje efikasnost (brzinu), ali i pravnu vrijednost odluke koja će se donijeti. Nešto slično ulozi istrage u pripremi rasprave u kaznenom postupku. 
Njihova je uloga (pa i njihov status) drukčija od uloge sudskih savjetnika pri redovnim sudovima. Ustavnosudski savjetnici, naime, u pravilu predstavljaju pravne stručnjake više razine spremnosti, a dragocjeni su suradnici i pomoćnici sudaca Ustavnog suda. Posebno moraju biti važni kada specijalizirano pokrivaju neko posebno područje prava. ${ }^{38}$

Suci Ustavnog suda tijekom postupka imaju i mogućnost koju nemaju suci redovnih sudova - da o određenim pravnim pitanjima zatraže stručno mišljenje od pravnih stručnjaka i znanstvenika koji se time specijalizirano bave. Poslovnik (t. 4. st.1. čl. 31.) ove suradnike Suda naziva "znanstveni savjetnici Ustavnog suda".

U proteklih 27 godina Ustavni sud je dosta koristio mogućnost traženja stručnog mišljenja (u 2431 predmetu).

Stručno-znanstveni značaj ovih "stručnih mišljenja" je vrlo upitan.

Suci Ustavnog suda su per definitionem "istaknuti pravnici" i ne zvuči uvjerljivo da suci takve razine pravne spreme traže "pomoć" koja se svodi na vještačenje o pravnim pitanjima. ${ }^{39}$

\subsection{Donošenje odluka}

O ustavnim tužbama se u Ustavnom sudu meritorno odlučuje u dva vijeća. Na plenumsko odlučivanje ide se kada u Vijeću nema suglasnosti ili je stvar od "šireg značaja" (st. 4. čl. 68. UZUS).

Sastav Ustavnog suda samo se iznimno može uzdržati od glasovanja (čl. 53. Poslovnika), onda ako je sudjelovao u donošenju odluke koja je predmet ustavnog pobijanja.

Kad se odlučuje na sjednici Ustavnog suda odluka se donosi većinom glasova svih sudaca (st. 1. čl. 27. UZUS i st. 1. čl. 45. Poslovnika). ${ }^{40}$

38 Aktualna organizacija u Ustavnom sudu je sada (od svibnja 2016. godine) takva da svaki sudac ima na raspolaganju po dva savjetnika. Ranije je dugo vladalo načelo "svi za sve suce" što je bilo dosta nekvalitetno. Novi model je svakako bolji, napose stoga što u većoj mjeri ističe primarnu ulogu suca-izvjestitelja. Treći je mogući model da se ustavnosudski savjetnici grupiraju po specijalnosti (građansko, kazneno, upravno, radno pravo). Takav model, npr. postoji u Sloveniji i njegova je prednost što onda ustavne suce opslužuju savjetnici većeg stupnja specijalnosti.

39 Njemački Savezni ustavni sud je npr. pred nekoliko godina slavio 60-godišnjicu postojanja pa je u prigodnom povijesnom pregledu svog rada između ostalog naveo i uporabu stručnih mišljenja, rekavši da se Sud u čitavoj svojoj povijesti time poslužio samo dva puta i da žali što je to učinio. Takva mogućnost u njemačkom pravu više ne postoji (M. Sachs, op. cit., str. 171.). Teško je i inače braniti tezu da suci redovnih sudova (u pravilu pravnici niže spreme i iskustva) nemaju blagodat traženja znanstvenih "stručnih mišljenja" (nego ih nemilosrdno prati fikcija "iura novit curia”), a da pravo na "jocker zovi” imaju "istaknuti pravnici” u Ustavnom sudu. Potrebnu (i nužnu) vezu sa strukom i znanosti suci Ustavnog suda moraju održavati na drugi način - praćenjem domaće i inozemne stručne i znanstvene literature. Poslovnik US (čl. 85.) predviđa postojanje knjižnice koja bi trebala pomoći u tom smislu.

40 Kod plenumskog odlučivanja većinom se može dogoditi i to da npr. u manjini ostanu sudacizvjestitelj i predsjednik Ustavnog suda koji supotpisuju donesenu odluku (st. 4. čl. 55. Poslovnika). S obzirom na to da, po naravi stvari, oni i pišu odluku, može nastati vrlo izazovna situacija koju ni UZUS ni Poslovnik ne rješavaju. Do sada se u Ustavnom sudu tako nešto nije dogodilo. 
Ni UZUS ni Poslovnik ne sadrže poznato pravilo redovnih sudskih postupaka (npr. st. 1. čl. 334. ZPP) da je Sud za svoju odluku vezan od trenutka otpreme.

Između donošenja i otpreme odluke moguće su situacije koje razumno nalažu određenu promjenu odluke. Na civilnoj redovnoj sudskoj razini to se rješava ponovnim otvaranjem rasprave (čl. 305. ZPP), ali na ustavnoj posebnog rješenja nema pa bi po čl. 34. UZUS-a trebalo koristiti postupovne radnje redovnih sudova.

Meritorna odluka po ustavnoj tužbi je ili odbijajuća (čl. 75. UZUS) ili usvajajuća (čl. 74., st. 1. čl. 75. UZUS).

Razlozi odbijanja su jasni ("ne postoje razlozi zbog kojih se akt osporava"), ali razlozi mogućeg ukidanja pobijenog akta nisu jasno postavljeni.

"Obrnutim" čitanjem čl. 75. UZUS-a dalo bi se zaključiti da će ukidna odluka uslijediti kada postoje razlozi zbog kojih se akt pobija.

Takva situacija nije dobra i ona otvara mogućnosti nepredvidljivog zadiranja u akte (odluke) redovne sudske vlasti.

Redovni sudovi u okviru svojih nadležnosti (viši i najviši sud) ukidaju pravorijek suda nižeg stupnja samo iz točno određenih razloga - zbog pogrešno ili nepotpuno utvrđenog stanja ili i zbog počinjene povrede postupka (relativno ili apsolutno bitne). $\mathrm{Na}$ toj razini pojmovno ne ide ukidanje zbog pogrešne primjene materijalnog prava (tada se preinačuje pobijena odluka).

Tijek vremena po naravi jača redovan sudski pravorijek i pobijani akt se može ukinuti na ustavnoj razini zbog povrede postupka samo zbog težih povreda u odnosu na one zbog kojih se može ukinuti u žalbenom postupku, odnosno revizijskom postupku. U protivnom ruši se konzistentnost ukupnoga pravnog sustava. ${ }^{41}$

Iz opisa traženog sadržaja ustavne tužbe (čl. 65. UZUS) proizlazilo bi da se redovno sudski utvrđene činjenice ne bi mogle pobijati pred Ustavnim sudom.

U ovom radu već je spomenuto pitanje načelne postupovne nespojivosti ukidanja akta redovnog suda zbog pogrešne primjene materijalnog ustavnog prava. Teško je braniti rješenje UZUS-a da se i onda ukida pobijeni akt.

O svim relevantnim pitanjima sudac Ustavnog suda se kod odlučivanja izjašnjava o tomu podržava li prijedlog odluke ili ne.

Pritom ima zapravo dvije, čak tri mogućnosti: da glasuje "protiv", da pisano obrazloži svoje suprotno glasovanje ako to nije usmeno iznosio (st. 5. čl. 27. UZUS, čl. 52. Poslovnika) i da daje "izdvojeno mišljenje" (st. 4. čl. 27. UZUS, čl. 50. Poslovnika).

Ova treća situacija posebno je zanimljiva. "Izdvojeno mišljenje" (njem. Sondervotum, engl. dissenting vote ili dissenting opinion, tal. opinione diversa ili opinione separata) je pravo (mogućnost) ustavnog suca da kada glasuje protiv većinski usvojene odluke, uz izjavljeno protivljenje, može dodatno u pisanom obliku obrazložiti svoje neslaganje koje se objavljuje zajedno s većinski donesenom odlukom.

Ideja i praksa "izdvojenih mišljenja" inače su "uvezene" iz anglosaksonskoga

41 Ovo je zasigurno jedno od težih pitanja ustavnosudskog postupka po ustavnim tužbama. Jednostavno rečeno - ne bi smjelo na Ustavnom sudu pobijana odluka biti ukinuta ako su razlozi takvi da ukidanje nije moguće ni u revizijskom ni u žalbenom postupku. Pred Ustavnim sudom razlozi ukidanja moraju biti mnogo teži. 
pravnog područja. Europa je prema tom institutu načelno dosta rezervirana. Njemačka, npr. tek od 1963. poznaje Sondervotum, a Austrija ga ne poznaje. ${ }^{42}$

U redovnom sudstvu takva mogućnost ne postoji, pa se može reći da mogućnost davanja "izdvojenog mišljenja" danas postoji samo kod ustavnih sudova (također i kod nekih međunarodnih sudova).

Kritičari "izdvojenih mišljenja" tvrde da to slabi i relativizira autoritet donesene (tj. većinski donesene) sudske odluke. Po njima to "zbunjuje" građane koji uz važeću odluku vide i suprotnu "odluku" drukčijeg sadržaja (koju je napisao sudac najvišeg stupnja stručnosti).

U prilog "izdvojenih mišljenja" može se, s druge strane, navesti da ona pokazuju povećani angažman svih sudaca, da se time svaki pojedini sudac specifično profilira i opće i profesionalno (na što građani imaju pravo i što očekuju od Ustavnog suda) i da u ukupnosti podižu razinu ustavnosudskog odlučivanja kao najviše razine stručnoznanstvenog i ustavno-sudsko etičkog razmišljanja o određenim pravnim pitanjima.

Čini se da pretežu razlozi u korist postojanja instituta "izdvojenog mišljenja", pa je dobro što suci Ustavnog suda imaju to pravo i mogućnost.

Nema razloga da slično pravo nemaju i suci redovnih sudova. U prva dva stupnja suđenje već prevladava monokratski sustav suđenja (i tu onda problem ni ne postoji), ali na višim razinama redovnog suđenja (napose na najvišoj razini, na Vrhovnom sudu) pitanje ostaje otvoreno i nema razloga da se blagodat "izdvojenog mišljenja" ne priznaje i sucima redovnih sudova.

"Izdvojeno mišljenje" se u pravilu i najčešće odnosi na izreku većinski donesene odluke, ali se može odnositi i samo na obrazloženje, naravno može i na jedno i na drugo (st. 1. čl. 50. Poslovnika).

U praksi (u ovih 27 godina postojanja samostalne i neovisne države) suci Ustavnog suda rijetko koriste pravo na "izdvojeno mišljenje".

\subsection{Pravomoćnost odluka Ustavnog suda}

U postupanju redovnih sudova postoje uglavnom jasni standardi ključnih komponenti pitanja pravomoćnosti sudskih odluka (subjektivni, objektivni i vremenski aspekt pravomoćnosti).

$\mathrm{Na}$ ovome mjestu posebno nas zanima formalni aspekt pravomoćnosti, tzv. "formalna pravomoćnost" (ne bis in idem).

Na razini apstraktne kontrole ustavnosti propisa potpuno je jasno da se o tim pitanjima može ponovno raspravljati i odlučivati (čl. 54. UZUS).

$\mathrm{Na}$ razini ustavnosudskog odlučivanja po ustavnim tužbama stvari su nešto složenije.

D. Krapac govori o "promjeni pravnih stajališta u odlukama Ustavnog suda" i to ilustrira primjerom (odlukom) u primjeni Zakona o Hrvatskoj akademiji znanosti i

42 Jedan od većih protivnika "izdvojenog mišljenja” posebno je predsjednik austrijskog Ustavnog suda Gerhard Holzinger. Rasprava o tome se ipak povremeno otvara (Die Presse, 1.8.2016.), ali s malim šansama da austrijsko ustavno sudstvo prihvati ovaj institut. 
umjetnosti ${ }^{43}$ Praktički rečeno Ustavni sud po ovome može činjenično i pravno slične predmete različito rješavati i nije vezan odlukom ranije donesenoj u sličnim stvarima. ${ }^{44}$

U predmetu denacionalizacije (Odluka Ustavnog suda Republike Hrvatske, broj: U-III-5694/2013 od 1. ožujka 2016. ${ }^{45}$ Ustavni sud je išao još dalje - promijenio je pravno stajalište, ali je benefit te promjene priznao i svim podnositeljima ustavne tužbe koji su ranije bili odbijeni (bilo im je odbačena ustavna tužba zbog nepravovremenog podnošenja).

Slično bi npr. bilo kada bi Vrhovni sud o nekom pitanju promijenio pravno stajalište (npr. da nešto što je ranije odbijano u buduće predstavlja relevantnu neimovinsku štetu koja se popravlja novcem) i da u odluci pozove sve ranije tužitelje koji su bili odbijeni na podnošenje nove tužbe koja neće biti odbačena zbog mogućeg prigovora presuđenosti. zamislivo.

Čini se da u redovnoj sudskoj praksi tako nešto nije moguće, vjerojatno nije ni

Ustavnom sudu mora se priznati pravo na "korak više", ali je - s obzirom na opisana dva konkretna slučaja - pitanje do koje granice može ići taj ustavnosudski aktivizam. Mora se pritom, naime voditi računa i o nekim materijalnopravnim aspektima pravomoćnosti (npr. da stranka koja je dobila i ustavni spor maksimalno slobodno raspolaže svojom stvari ili pravom, bez rizika da će itko to naknadno opozvati).

\section{ZAKLJUС̆ AK}

Ustavni sudovi su, povijesno gledano, relativno novija institucija državne vlasti. Još je kasnija i njihova nadležnost u rješavanju ustavnih tužbi, što je u različitim državama i vrlo različito organizirano.

Mi smo prihvatili njemački model dopustivosti ustavne tužbe protiv odluke svake državne vlasti, jasno uz pretpostavku da su prethodno iscrpljene redovne sudske (redovne pravne) mogućnosti. Time se ustavnosudska zaštita u području ustavnih tužbi ukazuje kao supsidijarna pravna zaštita.

Ograničen, čak vrlo ograničen postotak usvajanja ustavnih tužbi (od 1 do $3 \%$ na europskoj razini, oko $1 \%$ u Njemačkoj, oko $3 \%$ u Hrvatskoj) napose ima priličnu sociološko-pravnu vrijednost jer omogućuje Ustavnom sudu vrlo relevantnu ocjenu o ukupnom funkcioniranju pravnog poretka. ${ }^{46}$

43 D. Krapac, op. cit., str. 106.-107.

44 U slučaju HAZU-a (Odluka Ustavnog suda Republike Hrvatske, broj U-III/4947/2008 od 7. srpnja 2010.) mogu se ipak primijetiti dva teoretski (a i praktično) važna problema: prvo što se pravo na punu tržišnu (komercijalnu) cijenu za nacionalizirane zgrade priznaje samo jednom subjektu (HAZU) i drugo, što se obveza nadoplate nalaže subjektu koji nije sudjelovao u redovnom sudskom sporu (Državi). Nije bez dvojbe ni stav da se promjena pravnog stajališta temelji na primjeni konvencijskih pravila o "pravu na mirno uživanje vlasništva" (ta su pravila bila na snazi i poznata i u vrijeme odlučivanja u ranijim sličnim predmetima gdje su svi podnositelji ustavne tužbe bili odbijeni).

45 Narodne novine, br. 27/16.

46 C. Pestalozza (op. cit., str. 33.) ističe da ograničeni (“die geringe”) broj uspješno uloženih ustavnih 
Razlog je to od takva značaja da opravdava daljnje napore na konstrukciji "ustavnog postupovnog prava" kao neophodne karike tog ukupnog lanca ustavnopravne zaštite.

Čini se da postoje svi razlozi da se instituti "ustavnog postupovnog prava" smisleno nadovežu na one koje već postoje $u$ redovnom sudskom pravu ${ }^{47} \mathrm{i}$ da tek potom ide u sferu nužne i posebne specijalnosti i specifičnosti.

Raspravu o Ustavnom sudu (i ustavnom sudstvu općenito) treba s medijske i političke scene preusmjeriti na stručno-znanstvenu scenu koja je do sada bila nekako najtiša.

To bi ujedno bio dragocjen doprinos podizanju stručno-znanstvene kompetencije Ustavnog suda, ali također i prilog povećanju njegova ugleda kao dostojanstvenog zaštitnika ustavnih prava građana.

Ovaj je rad skromna pomoć nastojanjima da se ustavnosudska nadležnost $\mathrm{u}$ ustavnim tužbama podigne na višu znanstveno-stručnu razinu. Postojeća već skoro trodecenijska praksa Ustavnog suda daje razloga za kritiku, ali daje u isto vrijeme i mnogo razloga za ohrabrujuću ocjenu da su pomaci mogući i da će oni u budućnosti biti još veći.

Odlučivanje Ustavnog suda po ustavnim tužbama nije nekakva pričuvna (rezervna) opcija ustavnog suđenja i nije statističko opravdanje angažiranja povećeg broja sudaca i njihovih suradnika, nego mora biti pravi vrh piramide zaštite ustavnih prava građana.

U tom smislu valjalo bi krajnje ozbiljno pristupiti promjeni temeljnih projekcija vezanih za nadležnost Ustavnog suda u ustavnim tužbama, a neke bi stvari već i sada trebalo riješiti ili ispraviti. ${ }^{48}$

\section{LITERATURA}

1. Bin, R., Pitruzella G., Diritto costituzionale, Torino, 2000.

2. Krapac, D., Postupak pred ustavnim sudom RH, Ustrojstvo i proceduralni elementi nadzora, Zagreb, 2014.

3. Pestalozza, C., Die echte Verfassungsbeschwerde, Berlin,2006.

4. Sachs, M., Verfassungsprozessrecht, Tübingen, 2010.

5. Sinović, D., Ustavna žalba, teorijsko-pravni okvir, Anali Pravnog fakulteta u Beogradu, br. $1 / 2012$.

tužbi pokazuje dobro funkcioniranje pravnog poretka (“.. das der oben Verfassungsgerichten vorgeschaltete Rechtsweg sinvoll ist und das funktioniert").

47 Zanimljivo je da supsidijarnu primjenu pravila redovnog sudskog postupka u ustavnosudskom postupku predviđa i npr. austrijsko pravo i to tako što predviđa supsidijarnu primjenu pravila parničnog postupka. U jednom od značajnih udžbenika austrijskog ustavnog prava (Walter/ Mayer/Kucsko-Stademayer, Bundesverfossungsrecht, Wien, 2007., str. 505.-506.) ovo se rješenje kritizira kao vrlo problematično ("problematisch") jer da produžuje važenje sasvim drugih pravila postupka.

48 To se npr. odnosi na odredbu UZUS-a (al. 1. čl. 79.) da se postupak pokrenut ustavnom tužbom obustavlja "kada podnositelj ustavne tužbe umre". U građanskom pravu (odakle je i najviše ustavnih tužbi) subjektivna su prava načelno, pretežno prenosiva i samo su iznimno neprenosiva. Smrt stranke razlog je samo za prekid postupka, kako je u parnici (al. 1. čl. 212. ZPP), tako treba biti i u ustavnom postupku. 
6. Smerdel, B., Sokol, S., Ustavno pravo, Zagreb, 2006.

7. Triva, S., Dika, M., Građansko parnično procesno pravo, Zagreb, 2004.

8. Walter/Mayer-Kucsko-Stadlmayer, Bundesverfassungsrecht, Wien, 2007.

9. Zagrebelsky, G., Diritto processuale costituzionale?, Milano, 1990. 
Summary

\section{RELATION BETWEEN ORDINARY AND CONSTITUTIONAL JUDICIAL PROCEDURES IN CONSTITUTIONAL COMPLAINTS}

This paper deals with relation between ordinary and constitutional judicial procedures in constitutional complaint. Constitutional protection against individual decisions of competent state authorities (mostly against decisions of ordinary courts) has supplementary nature. Citizens and legal entities may initiate procedure before the Constitutional Court only after exhaustion of ordinary legal remedies. Constitutional procedure is new judicial procedure, but it must take into account previous ordinary judicial procedures. It is new procedure because the Constitutional Court has the right to implement its specific procedural rules. On the other hand, this procedure is old one. From previous ordinary judicial procedure originates the constitutional dispute and its proper settlement is not possible without conversance of this previous judicial procedure.

Keywords: Constitutional Court, constitutional procedure, constitutional complaint, ordinary courts, ordinary judicial procedure, constitutional procedural law, judges, Constitution of the Republic of Croatia, Constitutional Act on the Constitutional Court of the Republic of Croatia, Rules of Procedure of the Constitutional Court of the Republic of Croatia.

\section{Zusammenfassung}

\section{ZUSAMMENHANG ZWISCHEN ORDENTLICHEM UND VERFASSUNGSRECHTLICHEM VERFAHREN IN VERFASSUNGSBESCHWERDEN}

Diese Arbeit befasst sich die Beziehung zwischen ordentlichen und verfassungsrechtlichen Verfahren in Verfassungsbeschwerden. Der Verfassungsschutz gegen einzelneAktederzuständigen staatlichen Organe, vorallemgegen Entscheidungen der ordentlichen Gerichte, ist subsidiär, d.h. Bürger und juristische Personen können ihre Beschwerden einreichen, nachdem sie andere rechtlichen Möglichkeiten im ordentlichen Verfahren ausgeschöpft haben. Der Verfassungsgerichtsprozess ist zwar ein neues Verfahren, kann aber nicht so neu sein, dass es sich auf die Grundlagen des ordentlichen Gerichtsverfahrens nicht bezieht.

In diesem Sinne ist der Verfassungsprozess vor dem Verfassungsgericht sowohl "neu" als auch "alt", d.h. neu soweit das Verfassungsgericht das Recht auf seine besondere und spezifische Standardbehandlung hat, und alt im Sinne, dass er sich nach denjenigen Regeln der regelmäßigen Behandlung richtet, aus 
denen der Verfassungsstreit entstanden ist und ohne dessen Kenntnis ein korrekter verfassungsrechtlicher Abschluss nicht möglich wäre.

Schlüsselwörter: Verfassungsgericht, Verfassungsgerischtswesen, Verfassungsprozess, Verfassungsbeschwerde, ordentliche Gerichte, regelmäßiges Gerichtsverfahren, der Verfassungsprozessrecht (Verfahrensrecht), Richter der Verfassungsgerichte, Richter der ordentlichen Gerichte, Verfassung der Republik Kroatien, Verfassungsgesetz über das Verfassungsgericht der Republik Kroatien, Verfassungsgericht der Republik Kroatien.

Riassunto

\section{IL RAPPORTO TRA IL PROCEDIMENTO GIUDIZIARIO ORDINARIO ED IL PROCEDIMENTO GIUDIZIARIO COSTITUZIONALE NEI RICORSI COSTITUZIONALI}

Il presente lavoro tratta del rapporto tra il procedimento giudiziario ordinario ed il procedimento giudiziario costituzionale nei ricorsi costituzionali.

La tutela costituzionale avverso gli atti degli organi competenti del potere statale (in particolare avverso le decisioni dei tribunali ordinari) ha carattere sussidiario: i cittadini e le persone giuridiche possono adire la Corte costituzionale della Repubblica di Croazia soltanto dopo avere esaurito tutti gli strumenti volti a risolvere in via ordinaria una controversia.

Il procedimento costituzionale è un procedimento nuovo, ma non può e non deve essere nuovo a tale punto da non seguire le regole del procedimento giudiziario ordinario.

In tale senso il procedimento costituzionale dinnanzi alla Corte costituzionale è sia "nuovo", che "vecchio"; nuovo in quanto la Corte costituzionale ha diritto a proprie norme procedurali determinate e specifiche; vecchio in quanto segue le regole della procedura ordinaria dalle quale è poi derivato il contenzioso costituzionale ed in difetto della conoscenza delle medesime non sarebbe possibile una regolare conclusione del procedimento costituzionale.

Parole chiave: Corte costituzionale, giustizia costituzionale, procedimento costituzionale, ricorso costituzionale, tribunali ordinari, procedimento giudiziario ordinario, diritto processuale costituzionale, giudici delle corti costituzionali, giudici delle corti ordinarie, Costituzione della Repubblica di Croazia, Legge costituzionale sulla Corte costituzionale della Repubblica di Croazia, Regolamento della Corte costituzionale della Repubblica di Croazia. 
